Ecological Applications, 1998, v.8, iss.1, p.88-103.

http://www.esajournals.org/perlserv/?request=index-html\&ct=1

http://www.esajournals.org/doi/pdf/10.1890/1051-0761(1998)008\%5B0088\%3ARDDSOL\%5D2.0.CO\%3B2

ISSN: 1051-0761

doi: 10.1890/1051-0761(1998)008[0088:RDDSOL]2.0.CO;2

(C) 1998 Copyright by the Ecological Society of America

\title{
RIVER DISCHARGE DRIVES SURVIVAL OF LARVAL WALLEYE
}

\author{
Joseph B. Mion, Roy A. Stein, and Elizabeth A. Marschall
}

Aquatic Ecology Laboratory, Department of Zoology, The Ohio State University.

\begin{abstract}
Walleye (Stizostedion vitreum) in Lake Erie have historically experienced large fluctuations in recruitment success, which have important implications for walleye population dynamics as well as food web interactions. Because walleye year class strength in Lake Erie likely is set during the larval life stage, we explored factors underlying larval survival during out-migration in the Maumee and Sandusky rivers, Ohio's primary walleye spawning tributaries. To evaluate our expectation that survival of larval walleye would be positively related to discharge, we estimated daily larval production and used otoliths to estimate hatch dates of larvae surviving out migration. Comparing daily larval production and survival distributions demonstrated strong temporal patterns of larval survival that were unrelated to daily larval production patterns. Daily survival varied greatly during the larval hatch ( 4 wk), with short, discrete periods (4-7 d) of high survival accounting for 75-84\% of total survivors. Contrary to our original expectations, larval survival was inversely related to river discharge $(P<0.05)$. As river discharge increased, the amount of suspended sediments increased $\left(r^{2}>0.6, P<0.001\right)$, likely directly increasing larval mortality. Post-out-migration densities of larval walleye in Maumee and Sandusky bays were correlated strongly (Maumee Bay: $r^{2}=0.99$, Sandusky Bay: $r^{2}=0.94$ ) with Ohio Division of Wildlife estimates of late summer juvenile abundance of Lake Erie walleye (which historically have been correlated strongly with year class strength). Because high discharge events during the larval hatch likely reduce survival, variability in river discharge underlies variability of walleye year class strength. Managers could mitigate these effects by reducing exploitation of spawning walleye and improving watershed characteristics to reduce discharge fluctuations and suspended sediments.
\end{abstract}

\section{Introduction}

Survival of juveniles of many species tends to be low and variable as compared to other life stages (Werner and Gilliam 1984). Interannual variability in the survival of early life stages strongly affects adult population dynamics across a wide range of taxonomic groups, including plants (Sacchi and Price 1992, Ostfeld and Canham 1993), marine invertebrates (Rough-garden et al. 1984), insects (Fischer and Moore 1993), fish (May 1974, Houde 1989, Leggett and DeBlois 1994), birds (DeSante 1990), and mammals (Kruule et al. 1991, O’Donoghue 1994). Quantifying mechanisms underlying this variability is necessary for a comprehensive understanding of population and, ultimately, community dynamics.

Understanding mechanisms governing year class strength of fishes has long been a primary goal in aquatic ecology because variable year class strength of juveniles produces equivalent variability in adult population size (Gulland 1982, Sissenwine 1984). Numerous hypotheses seek to explain interannual variability of year class strength of fishes, most of which have been concerned with early-life mortality resulting from interactions of abiotic and biotic factors with size and ontogeny of larval fishes (Miller et al. 1988, Sale 1990, Houde 1994, Leggett and DeBlois 1994). A broad suite of hypotheses continues to persist because few have been explicitly proven or disproven with any generality across species or systems, largely due to the complexity and subtlety of processes driving recruitment coupled with the often conflicting data presented by researchers pursuing single-factor causes of year class strength variability 
(Houde 1987, Pepin and Miller 1993, Leggett and DeBlois 1994). Recently, however, the utility of considering finer scales of variability among larval fish and environmental factors to establish causality has been effectively demonstrated. Rather than considering survival of annual cohorts of larval fishes as a whole, examining characteristics and survival of individual larvae or small aggregations of larvae (grouped temporally or spatially) within a year can provide greater insight into mechanisms driving year class strength (Methot 1983, Crecco and Savoy 1985, Crowder et al. 1992, Rice et al. 1993). Intraannual patterns of larval survival may elucidate mechanisms underlying inter-annual variability of year class strength, a perspective we pursued with riverspawning walleye (Stizostedion vitreum) populations in Lake Erie.

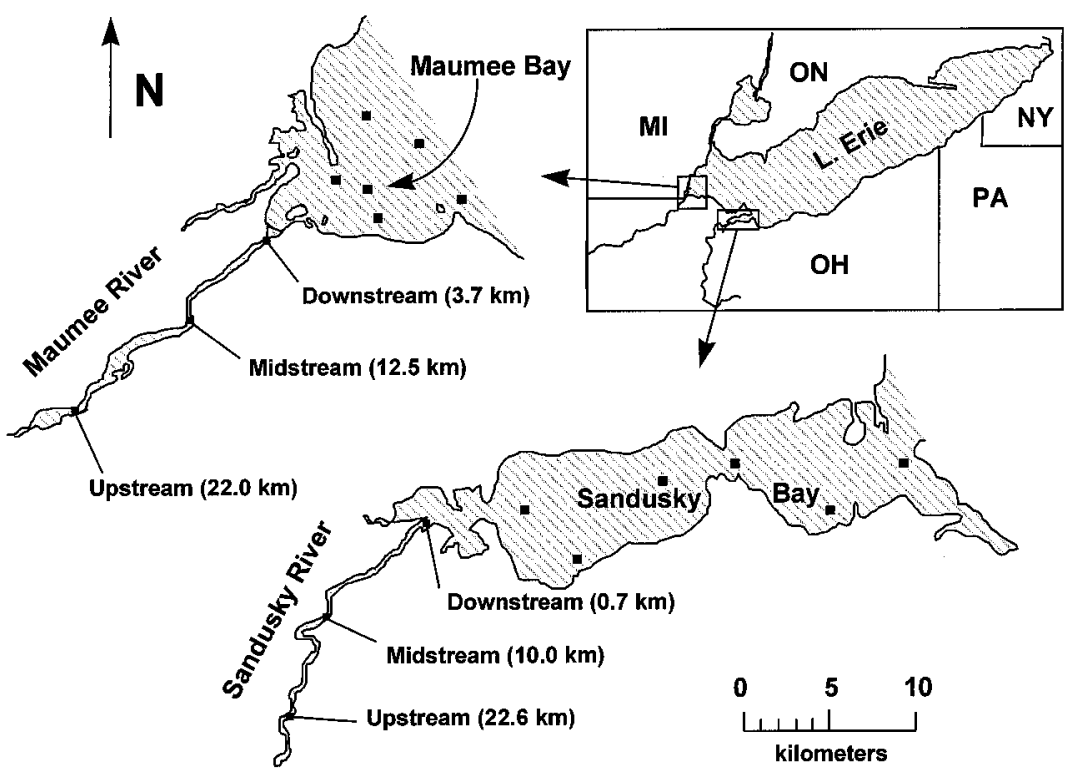

Fig. 1. Up-, mid-, and downstream sample sites ( $\mathbf{a})$ in the Maumee and Sandusky rivers and bays, Ohio, with approximate distances to the river mouth in parentheses. In the bays, the three sites closest to the river mouths constitute the "inner" bay sites whereas the three sites farthest from the river mouths constitute the "outer" bay sites.

As the terminal predator and valued sport and commercial fish, walleye are important both ecologically and economically in Lake Erie. Like most populations of walleye (Ney 1978), those in Lake Erie have exhibited large variations in year class strength (Hatch et al. 1987). Previous studies have attributed this variability to abiotic factors (e.g., temperature and storm events; Busch et al. 1975), species interactions (Hartman 1972), overfishing, and human-induced ecosystem alterations (e.g., excessive nutrient input, invasions of exotic species, and degradation of riverine spawning areas; Leach and Nepsy 1976, Schneider and Leach 1977). With a long history of these perturbations (Regier and Hartman 1973, Schneider and Leach 1977), Lake Erie is a difficult and uncertain environment for fisheries managers. Developing an understanding of variations in walleye year class strength would improve the ability of managers to predict broadscale trends in the Lake Erie fish community in response to continually changing conditions and to more precisely target management efforts. 
Herein we quantify mechanisms underlying year class strength of Lake Erie walleye, specifically those that spawn in the Maumee and Sandusky rivers, Ohio, concentrating on river out-migration of larval walleye to nursery areas in the bays. Early life stages of river-spawning walleye, like many marine and freshwater fishes, rely on physical transport mechanisms (river discharge for walleye) to carry them from hatch sites to distant nursery areas (Norcross and Shaw 1984). Both deterioration of these currents (Nelson et al. 1977, Shelton and Hutchings 1982) and anomalous hydrographic events (Baily 1981) can be related to poor survival and hence poor year class strength. Clearly, success of larvae in reaching nursery areas, coupled with coincident environmental conditions, probably has profound implications for recruitment variability of fishes. For walleye specifically, high environmental variability within food-poor rivers coincides with critical stages of walleye ontogeny, indicating a possible cause of variability in year class strength. Given that prolonged river residence time may reduce larval survival through starvation (Priegel 1970), we tested the hypothesis that strong larval survival was positively related to rapid out-migration from rivers, resulting from high discharge, by quantifying daily production and survival of larval walleye in the Maumee and Sandusky rivers during 1993-1995. By understanding field patterns of survival of larval walleye, we gain important insights into walleye population dynamics, ultimately improving our ability to predict and manage fish community dynamics within a changing ecosystem.

\section{Methods}

Study area

As Ohio's two largest tributaries to western Lake Erie, the Maumee and Sandusky rivers (Fig. 1) drain largely agricultural and urban areas (16 395 and $3240 \mathrm{~km}^{2}$, respectively), thus carrying high suspended sediment and nutrient loads (United States Geological Survey [USGS] 1992). Mean daily discharges tend to be about four times greater in the Maumee River than in the Sandusky River (USGS 1992). Low gradients and the strong intrusive effect of Lake Erie seiches generate low current velocities (typically $<10 \mathrm{~cm} / \mathrm{s}$ near the river mouths, this study), making flow reversals common in both rivers (Bedford 1992). Gravel riffles, used by spawning walleye, began $\sim 25 \mathrm{~km}$ upstream of the mouths in each river. In the Sandusky River, upstream movement of walleye was limited by the Ballville Dam in Fremont, Ohio, whereas no such impediment existed in the Maumee River. Each river empties into a large bay (Maumee Bay: 5441 ha, Sandusky Bay: 14692 ha), with depths typically 2-3 m.

\section{Field data collection}

We sampled the Maumee and Sandusky rivers and bays each spring during 1993-1995. Three sample sites were established in each river: (1) an upstream site immediately below walleye spawning riffles, (2) a midstream site about midway between spawning areas and the river mouth, and (3) a downstream site near the river mouth (Fig. 1). Sites were chosen such that physical parameters (depth, width, etc.) were as uniform as possible. All sites were sampled twice weekly in 1993 and three times weekly in 1994-1995 during late March through early June, a period encompassing hatching and river residence of larval walleye. Our river sampling was designed to quantify spatial and temporal trends in larval walleye density, movement, and survival, as well as environmental conditions, during out-migration. We also sampled weekly in the bays to quantify densities of larval walleye surviving out-migration. In 1993, we sampled three bay sites twice each week. To increase our resolution in larval walleye densities, we sampled bays on a finer spatial scale (six sites weekly) in 1994-1995. 
We collected biotic and abiotic environmental data at each sample site. Zooplankton were sampled using 31-cm diameter, $153-\mu \mathrm{m}$ mesh nets lowered to the bottom, hauled to the surface vertically (to provide a sample of the entire water column), and preserved in $70 \%$ ethanol. We followed the methods of Stahl and Stein (1994) to estimate zooplankton density. Samples were rinsed onto a small, circular counting dish divided into 16 sectors. Under a dissecting scope, individuals of each taxon in one-eighth of the dish were counted; these numbers then were used with the following formula to project the total number of individuals in the entire sample:

$[($ no. counted $)(1 /$ fraction of dish counted $) \times(1 /$ fraction of sample in dish $)]$.

If the projected number of individuals of a taxon was $<25$, we stopped counting that taxon. If the projected number was $>25$, then $>50$ individuals of that taxon were counted. After completing the section in which the 50th individual was counted, we stopped counting that taxon, and again projected the total number of individuals in the sample. Lengths of the first 22 individuals of each taxon encountered were measured (total body length, excluding spines, helmets, and caudal rami) using a digitizing pad and microcomputer. Zooplankton lengths were converted to biomass using taxon-specific length-dry mass regressions (G. G. Mittelbach, Kellogg Biological Station, Michigan State University, East Lansing, Michigan, unpublished data).

Surface water temperatures were taken at $1 \mathrm{~m}$ depth on each sampling date. Daily discharge and total suspended sediment data were obtained from United States Geological Survey gauges on both rivers (USGS 1995).

To collect walleye larvae in the rivers and bays, we towed $1 \times 2 \mathrm{~m}$ (mouth size) neuston nets equipped with flow meters to measure the volume filtered during each tow. Only 500micron mesh nets were used for river sampling, whereas various net meshes (500-, 1000-, 1800$\mu \mathrm{m}$, with successively larger meshes used as average larval walleye size increased) were used in the bays. Nets were towed through the top meter of the water column at $\sim 1-1.5 \mathrm{~m} / \mathrm{s}$ for $3-5 \mathrm{~min}$ during daylight. Only the top meter of the water column was sampled because larval walleye, being strongly photopositive (Bulkowski and Meade 1983), drift mostly in the upper water column (Franzin and Harbicht 1992). We completed two tows at each site on each sampling date (towing once upstream and once downstream). Because ichthyoplankton are often unevenly distributed within rivers (Corbett and Powles 1986, Harvey 1991), nets were towed diagonally to integrate samples across the width of the river. Upon collection, all ichthyoplankton were preserved immediately in 95\% ethanol. In the laboratory, we identified (Auer 1982) and counted walleye larvae. Larval density was calculated as the number of larvae captured during a tow divided by the volume filtered (in cubic meters). For each sample date, we weighed $(0.1 \mathrm{mg}$ wet mass) and measured (0.1 $\mathrm{mm}$ TL) up to 20 walleye larvae from each site.

We analyzed larval walleye collected at all river sample sites to quantify diets. We examined the entire digestive tract as guts from walleye larvae were essentially undifferentiated tubes and digestion rates were likely similar throughout the gut. All gut and stomach contents were identified and measured per methods described above for zooplankton.

\section{Larval production estimation}

To quantify survival of larval walleye, we first estimated daily and annual production of larval walleye in each river using data on mean density and variability of larvae at upstream sample sites. For these estimates, we assumed that (1) larval densities at upstream sites were composed solely of newly hatched larvae, as confirmed by analysis of otoliths from 40 larvae 
(larval walleye emerge from the substrate and begin drifting immediately upon hatching; Corbett and Powles 1986), (2) dates of first and final occurrence of walleye larvae in our upstream samples suggested true hatch duration (river sampling began before larvae appeared and ended after they disappeared), (3) all larvae drifted in the top $1 \mathrm{~m}$ of the water column, (4) samples taken at upstream sites each date were independent (i.e., larvae were transitory, thus we did not resample the same population of larvae on different sample dates at upstream sites), and (5) larval densities were uniform within the upstream area sampled and through time between sample dates (i.e., we could characterize larval density on a non-sampled date using density from the preceding sample date). We first estimated total volume of the section of river characterized by our upstream tows (river sample volume (V): 86450 and $22144 \mathrm{~m}^{3}$ for the Maumee and Sandusky rivers, respectively) from surface area measures on hydrographic maps of the section. To estimate daily numbers of newly hatched walleye drifting downstream, we combined estimates of walleye densities from our samples with estimates of flush rates of these sample sites. To calculate how many times river sample volumes were completely flushed each day of the larval hatch ( $f$; flushes per day), we divided daily river discharge (in cubic meters per day) by the river sample volume (in cubic meters). Daily river discharge was calculated for each day as river discharge rate (in cubic meters per second, from USGS gauging stations on each river) multiplied by 86400 (the number of seconds per day). We then estimated production of larval walleye for each day ( $P_{d}$; walleye larvae produced per day) as:

$$
p_{d}=W f V
$$

where $W=$ larval walleye density in our samples (number of larvae per cubic meter). We assumed that larval walleye densities estimated for each sample date did not change until the next sample date. We calculated total larval production $\left(p_{\mathrm{T}}\right)$ as the sum of daily larval production over all dates (both sampled and non-sampled).

Because we wanted to assign some measure of confidence to this estimate of total production, we derived an estimate of variance through the following steps. (1) Within-day variance of walleye density $\left(s_{\mathrm{w}}{ }^{2}\right)$ was calculated for each sample date from the two replicate neuston net tows, and, (2) Within-day variance of daily walleye production estimate $\left(s_{\mathrm{p}}{ }^{2}\right)$ was calculated by assuming a normal distribution of larval walleye densities. Variance of this estimate was calculated as

$$
s_{\mathrm{p}}{ }^{2}=s_{\mathrm{w}}{ }^{2}(f V)^{2} .
$$

(3) If we assume that sample dates are independent and that within-day variance on a given sample date also describes variance on subsequent non-sampled dates, then we can calculate variance of the sum of daily larval production (i.e., $s_{\mathrm{T}}{ }^{2}$, variance of total larval production) as the sum of the variances of daily production

$$
s_{\mathrm{T}}^{2}=\sum s_{\mathrm{p}}{ }^{2} .
$$


If samples were not truly independent, then variance of total larval production would be less than the calculated $s_{\mathrm{T}}{ }^{2}$; thus, our variance estimate may more accurately be thought of as a maximum variance. We calculated the standard error of total larval production $\left(\operatorname{SE} p_{\mathrm{T}}\right)$ as

$$
\frac{\sqrt{s_{\mathrm{T}}^{2}}}{\sqrt{n}}
$$

where $n=$ number of sample dates. The $95 \%$ confidence interval around $p_{\mathrm{T}}$ was then

$$
p_{\mathrm{T}}+\left(\operatorname{SE} p_{\mathrm{T}}\right)(1.96) .
$$

\section{Otolith analysis}

To quantify spatial and temporal trends in larval survival during out-migration, we used otolith analysis to estimate daily age and hatch dates of larval walleye caught at mid- and downstream sites in both rivers. Though these analyses would not tell us how quickly individuals moved downstream, we could gain insight into total river residence time (we refer to a larva's age at collection as its river residence time) for larvae and how it changed at each sample site during the hatch. For every sample date on which larval walleye were collected, we removed sagittal otoliths from up to 10 randomly chosen larvae from each site (total otoliths used $=920$ ). Otoliths were mounted whole on glass slides and cleared using a polyester resin, then were aged by a single reader using a transmitted-light microscope at $400 \times$ magnification. To avoid biasing counts, otoliths were read blindly; the reader knew neither date of capture nor size of larva. The reader randomly chose whether to read the left or right sagitta; ring deposition patterns did not differ between sides. Otoliths were read twice; if readings were within $10 \%$, larval age was taken as the mean of the two readings. If a second reading was not within $10 \%$, otoliths were read a third time; if any reading was not within $10 \%$ of the mean, the otolith was discarded. Hatch date for each larva was calculated as date of collection minus estimated age in days.

Knowing age at first increment deposition and periodicity of increment deposition is critical to accurate otolith analyses (Jones 1986). To address these issues, we collaborated with Edward Roseman (Department of Fisheries and Wildlife, Michigan State University, East Lansing, Michigan, USA) to conduct a marking experiment with larval walleye in 1994. Roseman gill-netted spawning adults on Lake Erie reefs to collect gametes that were used to culture larvae for this experiment. One day after hatching, 800-1000 larval walleye were marked in a solution of alizarin complexone for $2 \mathrm{~h}$. Alizarin complexone is absorbed into calcareous structures such as otoliths, leaving a red band that indicates the day of marking. Following marking, about half the larvae were placed in each of two enclosures in a 0.25 -ha pond. The enclosures allowed the fish to be exposed to in situ light and temperature regimes, both of which may influence patterns of otolith increment deposition (Jones 1986), and allow these results to be applied to wild-caught walleye larvae. Larvae were sampled at weekly intervals. Otoliths were processed and analyzed in the same way as those from wild-caught larvae. 
We collected 15 walleye larvae from the pond enclosures for analysis at the end of the first week of the marking experiment. Unfortunately, all walleye larvae in both enclosures died during the second week. All of the 15 known age $(8 \mathrm{~d})$ larvae collected from the first week aged to $8 \mathrm{~d}$ by their otoliths. Thus, consistent with Michaletz's (1986) findings, we concluded that first ring deposition occurred the day of hatch and that ring deposition in larval walleye was daily.

Because larval drift is likely passive (Corbett and Powles 1986), larval river residence time would likely be related to river discharge. We assessed this relationship by regressing mean river residence time on every sample date at the downstream sites on the mean daily discharge over the $5 \mathrm{~d}$ previous to each sample date. For both rivers, we pooled data across years and $\log _{10}(x+1)$ transformed both discharge and river residence time to stabilize the variance.

\section{Survival estimation}

We sought to determine the proportion of larvae attributable to individual hatch dates that survived to mid- and downstream sample sites. First, the distribution of hatch dates of larvae from mid- and downstream sites were compared to the full distribution of hatch dates to determine if mid- and downstream survivors were drawn randomly from all hatch dates. The full hatch date distribution was estimated from a distribution of daily larval densities at the upstream site, assuming that larvae collected on a given day at the upstream site represented larvae that had hatched that day. For each sample date at each site, we estimated the hatch date distribution from the otoliths of larvae sampled on that date and applied this distribution to the total density of larvae in that sample. Distributions of daily production (upstream site) were then compared to distributions of hatch dates of survivors from mid-and downstream sites using a chi-squared test. To evaluate the influence of daily production on the hatch date distribution of survivors, we regressed daily percent of total survivors at mid- and downstream sites on daily percent annual production. For these tests, proportions were arcsine square-root transformed (to stabilize the variance).

To evaluate spatial and temporal trends in larval survival during out-migration each year, we generated a daily index of survival (IS) for the mid- and downstream sites in both rivers. IS was calculated by dividing the total downstream density of larvae attributable to each hatch date by the estimated number of larvae produced that day. Thus, we had an IS value for each day of the larval hatch that allowed us to assess fine-scale variability in overall survival of larval walleye. To assess the effect of river discharge on larval survival, we plotted IS values against the average of daily discharges for five days following each hatch date. Similarly, we plotted IS against daily values of total suspended sediments to gauge how suspended sediments influence larval survival. Plots of IS and both discharge and suspended sediment suggested nonrandom relationships in which IS appeared to be limited beyond some threshold value of these two variables. Thus, we used a two-dimensional Kolmogorov-Smirnov (2DKS) test (Garvey et al. 1998) to test whether these distributions could have arisen by chance alone.

Because bays collect all larvae surviving river out-migration, we used annual peak densities of larval walleye in each bay as an index of survival of larvae spawned in the rivers. We also compared peak bay larval densities to Ohio Division of Wildlife (ODW) estimates of juvenile walleye catch-per-unit-effort (CPUE) in Lake Erie during August (Ohio Division of Wildlife 1996). This late summer index of juvenile abundance has been strongly correlated with walleye year class strength $(P=0.015$; M. Turner, Ohio Division of Wildlife, Fisheries Research Unit, Sandusky, Ohio, personal communication); hence, these analyses allowed us to examine the relationship between bay larval abundance and relative measures of walleye year class 
strength in Lake Erie.

We also examined the historical relationship between river discharge and juvenile walleye abundance by comparing river discharge in May (when the majority of larval walleye river residence occurred) to ODW estimates of juvenile walleye CPUE in Lake Erie during August (Ohio Division of Wildlife 1996). Because Lake Erie has historically been subject to great temporal variability in biotic and abiotic conditions, we used data from 1986-1992 (in addition to our study years), as these years (i.e., walleye population size, fish community structure, nutrient status, etc.) were most like our study period.

\section{Results}

Larval hatch

Larval walleye typically were produced during mid-April through mid- to late May in the Maumee and Sandusky rivers (Table 1). Mean hatch durations were $28 \pm 2.2 \mathrm{~d}$ (mean $\pm 1 \mathrm{SE}$ ) in the Maumee River and $29 \pm 4.0 \mathrm{~d}$ in the Sandusky River. Hatch duration did not differ between rivers across years (paired $t$ test; $P=0.58$ ).

\section{River discharge, water temperature, zooplankton density, and diets}

Within-year patterns of river discharge during the larval hatch were similar in both rivers across years. While the magnitude of discharge was greater in the Maumee River than in the Sandusky River (owing to the Maumee's much larger main channel), a visual comparison of their patterns of discharge revealed their similarity. River discharge varied greatly during the larval hatch, with peak discharges in all years occurring early in the hatch (usually mid-April). Discharge trends during larval walleye residence varied among years. In 1993 and 1994, discharge was low and stable in both rivers. Conversely, discharge was higher and more variable during 1995, with several high discharge events occurring in both rivers. River residence time of larvae was related inversely to river discharge in both the Maumee $\left(r^{2}=0.10, P=0.016\right)$ and Sandusky rivers $\left(r^{2}=0.28, P<0.0001\right)$, though it explained only a small proportion of the variance.

Table 1. Hatch period, estimated annual production, and peak bay density of larval walleye in the Maumee and Sandusky rivers, Ohio, during 1993-1995. Larval production was estimated using data on river volume, variability of larval density, and river discharge. Peak bay densities were estimated only from inner bay sample sites (see Fig. 1 ) as these likely provide the most accurate reflection of numbers of larvae entering the bay from the rivers.

\begin{tabular}{|c|c|c|c|c|c|}
\hline \multirow[b]{2}{*}{ System } & \multirow[b]{2}{*}{ Year } & \multirow[b]{2}{*}{ Hatch duration } & \multicolumn{2}{|c|}{$\begin{array}{l}\text { Production of } \\
\text { larval walleye }\end{array}$} & \multirow[b]{2}{*}{$\begin{array}{l}\text { Peak bay } \\
\text { density } \\
\text { (no./100 m } \\
\quad \pm 1 \mathrm{SE} \text { ) }\end{array}$} \\
\hline & & & Peak & $\begin{array}{l}\text { Millions } \\
\text { of larvae } \\
(95 \% \mathrm{CI})\end{array}$ & \\
\hline Maumee River & $\begin{array}{l}1993 \\
1994 \\
1995\end{array}$ & $\begin{array}{l}23 \text { April-16 May } \\
22 \text { April-24 May } \\
19 \text { April-18 May }\end{array}$ & $\begin{array}{r}29 \text { April } \\
1 \text { May } \\
12 \text { May }\end{array}$ & $\begin{array}{l}20.4(2.0) \\
13.4(1.2) \\
24.8(2.0)\end{array}$ & $\begin{array}{l}16.7 \pm 7.7 \\
27.3 \pm 8.7 \\
10.4 \pm 1.4\end{array}$ \\
\hline Sandusky River & $\begin{array}{l}1993 \\
1994 \\
1995\end{array}$ & $\begin{array}{l}21 \text { April-13 May } \\
18 \text { April-24 May } \\
17 \text { April-16 May }\end{array}$ & $\begin{aligned} & 27 \text { April } \\
& 9 \text { May } \\
& 11 \text { May }\end{aligned}$ & $\begin{array}{l}3.2(1.5) \\
3.0(0.2) \\
0.8(0.1)\end{array}$ & $\begin{array}{l}1.4 \pm 1.0 \\
4.6 \pm 1.9 \\
1.1 \pm 0.5\end{array}$ \\
\hline
\end{tabular}

As with discharge, annual patterns of water warming were similar across rivers. Trends in rate of water temperature increase did not differ between rivers, but did differ across years 
(ANCOVA, heterogeneity of slopes: river effect, $P=0.685$; year effect, $P<0.0001$; river $\times$ year interaction effect, $P=0.97$ ). Rate of warming was greater during 1995 than in 1993 and 1994, which did not differ (Tukey's multiple comparisons, $P<0.05$ ). Overall, temperature ranges were similar across rivers and years.

Zooplankton densities were extremely low at all sample sites in both rivers, typically $<1$ individual/L, during larval walleye residence (Fig. 2). In all years, zooplankton densities did not increase until late May, when larval walleye already had passed through the rivers. The one exception was at the downstream site in the Sandusky River during 1994 when densities increased in late April, becoming moderately abundant during walleye residence through May.

Larval walleye feeding success in the rivers was compromised by low zooplankton densities. Appreciable feeding occurred only at the downstream sites, and even there feeding rates were low. In the Maumee River, percentage of larvae from the downstream site having empty guts was $93.3(N=71), 81.4(N=59)$, and $98.3 \%(N=146)$ in 1993,1994 , and 1995 ; in the Sandusky River, these percentages were $76.9(N=69), 34.8(N=46)$, and $82.5 \%(N=40)$. Feeding was particularly successful in the Sandusky River during 1994, when zooplankton densities were unusually high.

\section{Larval production}

Estimated annual production of larval walleye differed markedly between, as well as within, rivers across years. The Maumee River produced 4.5-33 times more larvae than the Sandusky River each year (paired $t$ test, $\mathrm{P}=0.04$; Table 1). In the Maumee River, production differed among all years (non-overlapping 95\% CIs; Table 1). The Sandusky River produced similar numbers of walleye larvae during 1993 and 1994 (overlapping 95\% CIs), with both years exceeding 1995 production (non-overlapping 95\% CIs; Table 1).

Number of larvae produced per day ranged over several orders of magnitude within any one year. Because river discharge transports newly hatched larvae downstream, we examined the influence of river discharge on daily production by regressing daily production on daily discharge in each river. As expected given Eq. 1, daily production was related positively to daily discharge in each river; however, daily discharge explained only a very small proportion of the variation in daily production (Maumee River, all years pooled; $r^{2}=0.04 ; P=0.06$ : Sandusky River, all years pooled; $r^{2}=0.04 ; P=0.06$ ).

\section{Larval survival in rivers}

Larval survival varied greatly during the hatching period for walleye larvae in both rivers (Figs. 3 and 4). We found daily production and survival to be correlated at the midstream $\left(r^{2}=\right.$ $0.09 ; P=0.006)$ and downstream $\left(r^{2}=0.10 ; P=0.005\right)$ sites in Maumee River, though these relationships explained only $\sim 10 \%$ of the total variation. These two variables were unrelated at the Sandusky River midstream $\left(r^{2}=0.01, P=0.509\right)$ and downstream $\left(r^{2}=0.03, P=0.131\right)$ sites.

We used information from otoliths to help explain this poor correlation between larval production and survival to downstream sites. We first compared temporal distributions of larval production at upstream sites to hatch date distributions of survivors to midstream sites (determined by otoliths) and next compared hatch date distributions of survivors to midstream sites with hatch date distributions of survivors to downstream sites.

Hatch date distributions of larvae surviving to midstream sites dramatically differed from daily production distributions (Fig. $3, X^{2}$ test: $P<0.05$ both rivers, all years). Hatch date 
distributions of survivors to downstream sites differed somewhat from hatch date distributions of survivors to midstream sites (Fig. $4, X^{2}$ test: $P<0.05$ both rivers, all years except Sandusky River during 1995: $P=0.26$ ), but these differences were not nearly as pronounced as differences from larval production date distributions. Hatch dates characterized by high larval survival were not evenly distributed across the hatch duration, but rather were focused into short discrete periods. This phenomenon occurred at both mid- and downstream sites in each river across all years. Though hatches usually continued for $\sim 4 \mathrm{wk}$, most survivors derived from only $4-7 \mathrm{~d}$ each year (Table 2). Although these hatch periods accounted for $75-83 \%$ of the survivors to downstream sites, these dates accounted for only $5-52 \%$ of total larval production upstream. High survival timing was markedly consistent across years, always occurring from 27 April to 7 May in the Maumee River and 23 April to 4 May in the Sandusky River.

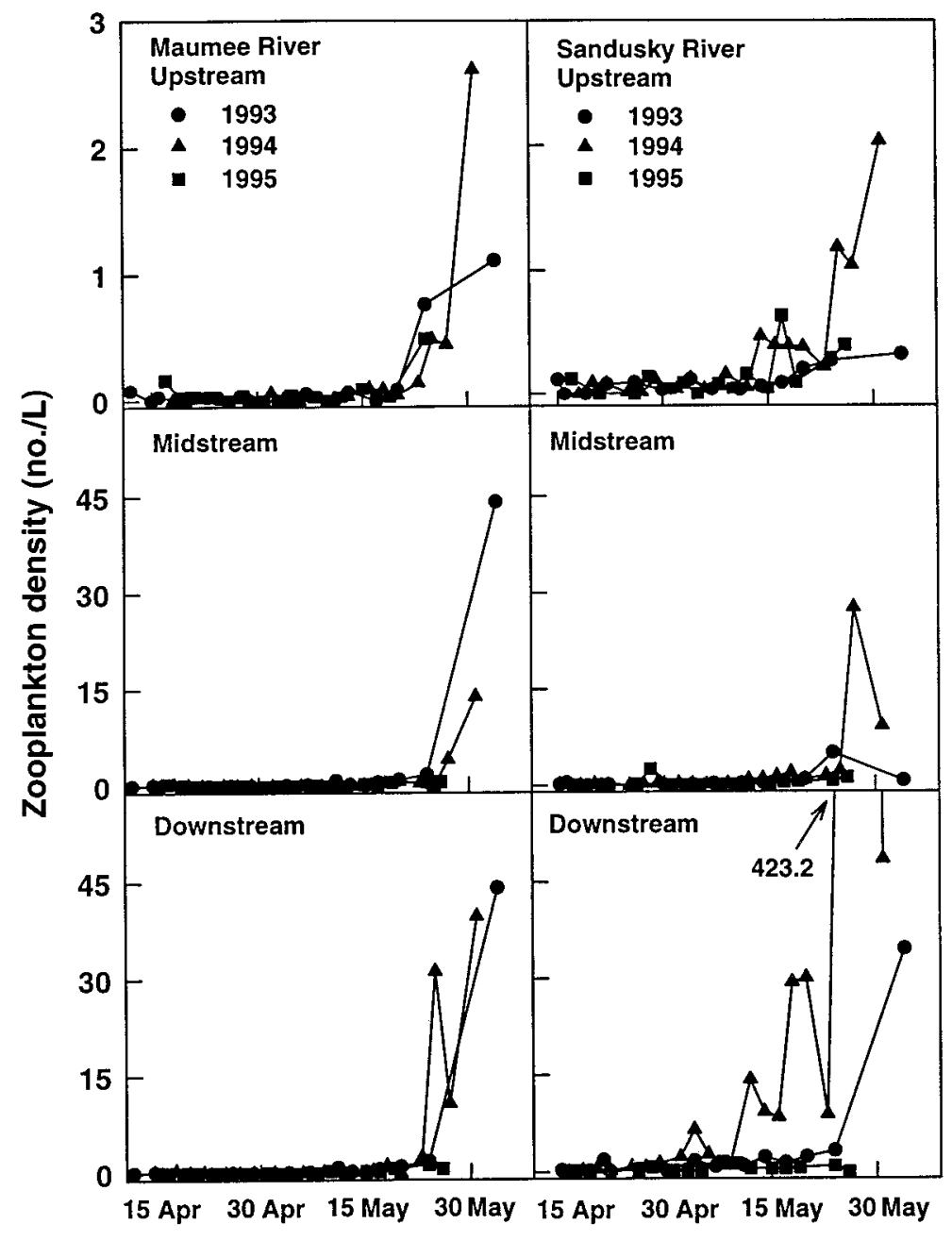

Fig. 2. Zooplankton densities at up-, mid-, and downstream sample sites in the Maumee and Sandusky rivers, Ohio, during 1993-1995. Note that the $y$-axis scale differs for upstream panels.

Patterns of hatch date distributions of survivors to mid- and downstream sites appeared to 
be driven by river discharge. Visual comparison of discharge with hatch date distributions of survivors to both mid- and downstream sites (Figs. 3 and 4) revealed that dates having relatively high survival typically occurred during periods of low discharge. Conversely, survival of larvae was low during high discharge events.

For each day larvae hatched, we calculated an IS (Index of Survival, see Methods: Survival estimation) value for larvae collected at mid- and downstream sites in each river. Comparing daily mid- and downstream IS values to river discharge revealed a dramatic inverse relationship between larval survival and discharge (Fig. 5), patterns which were nonrandom (2DKS test: midstream; $D_{\mathrm{BKS}}=0.053, P=0.043$; downstream; $D_{\mathrm{BKS}}=0.079, P<0.001$ ). Comparing daily IS values to suspended sediments, which were positively related to discharge (Maumee River, all years pooled; $r^{2}=0.68, P<0.001$ : Sandusky River, all years pooled; $r^{2}=$ $0.62, P<0.001$ ), revealed patterns similar to those resulting from discharge comparisons; distribution of midstream IS values were nonrandom when compared to suspended sediment values (2DKS test; $D_{\mathrm{BKS}}=0.070, P=0.003$ ); however, the distribution of downstream values was not significant (2DKS test; $D_{\mathrm{BKS}}=0.0512, P=0.072$ ). Still, this emphasized that days of high survival occurred only during very low discharge; even moderate discharge increases resulted in uniformly low survival. Survival of larval walleye was extremely variable at low discharges suggesting that low discharge was a necessary, but not sufficient, condition for high survival (Fig. 5). 


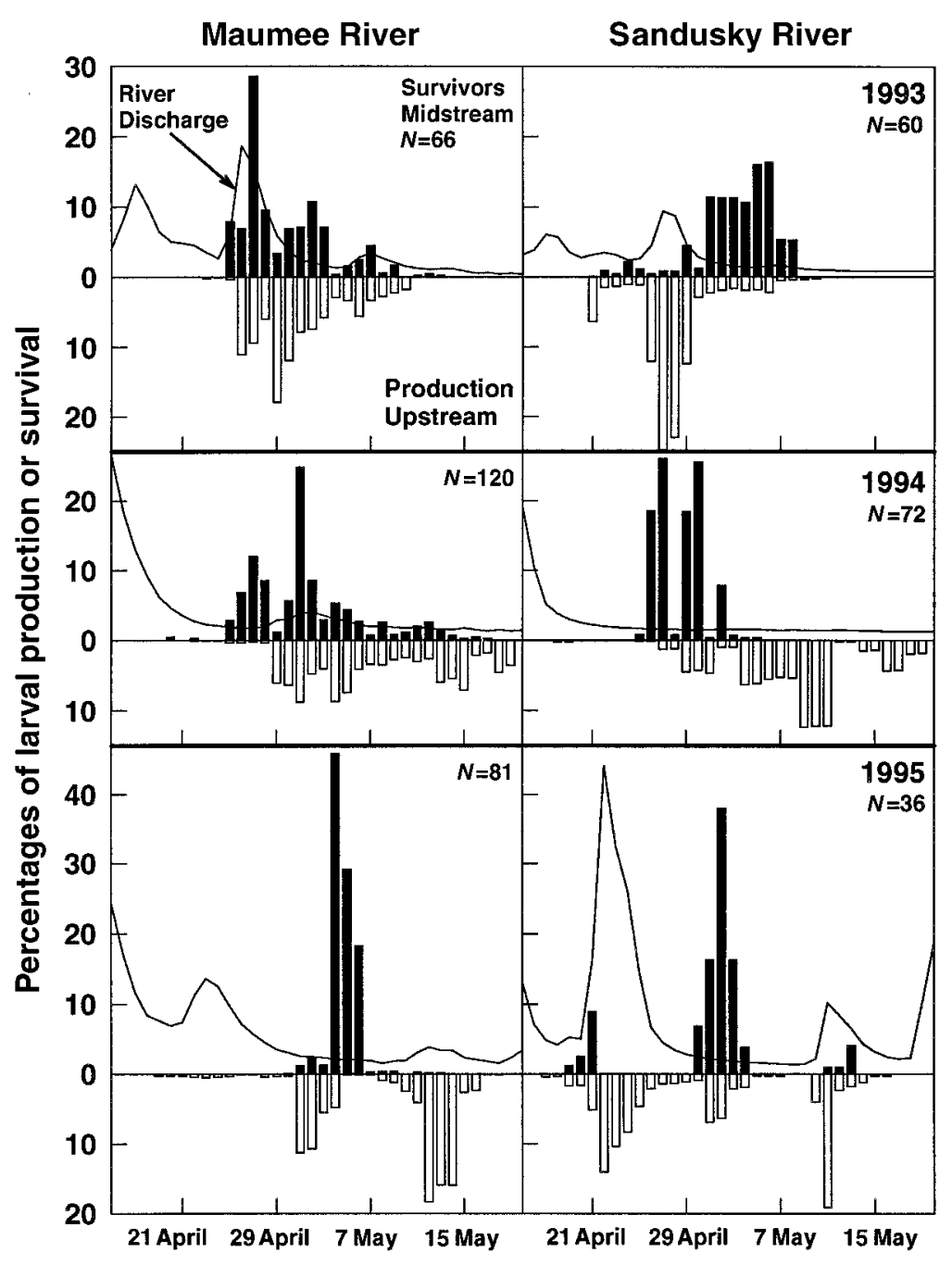

Fig. 3. Comparison between the distribution of larval walleye production from upstream sites (open bars) and hatch date distributions of survivors to midstream sample sites (filled bars) during 1993-1995 in the Maumee and Sandusky rivers, Ohio. Open bars represent daily percentages of total larval production, and filled bars represent daily percentages of total survivors to midstream sites attributable to individual hatch dates. To increase figure clarity, $y$ axes $\left(\mathrm{m}^{3} / \mathrm{s}\right)$ are not shown for discharge curves.

\section{Walleye recruitment}

Annual ODW estimates of inshore and offshore juvenile walleye CPUE in Lake Erie in late summer were correlated strongly with our estimates of peak bay density in June (Fig. 6). These ODW data revealed that 1994 was a strong walleye year class, 1993 was moderate, and 1995 was an extremely weak year class. 


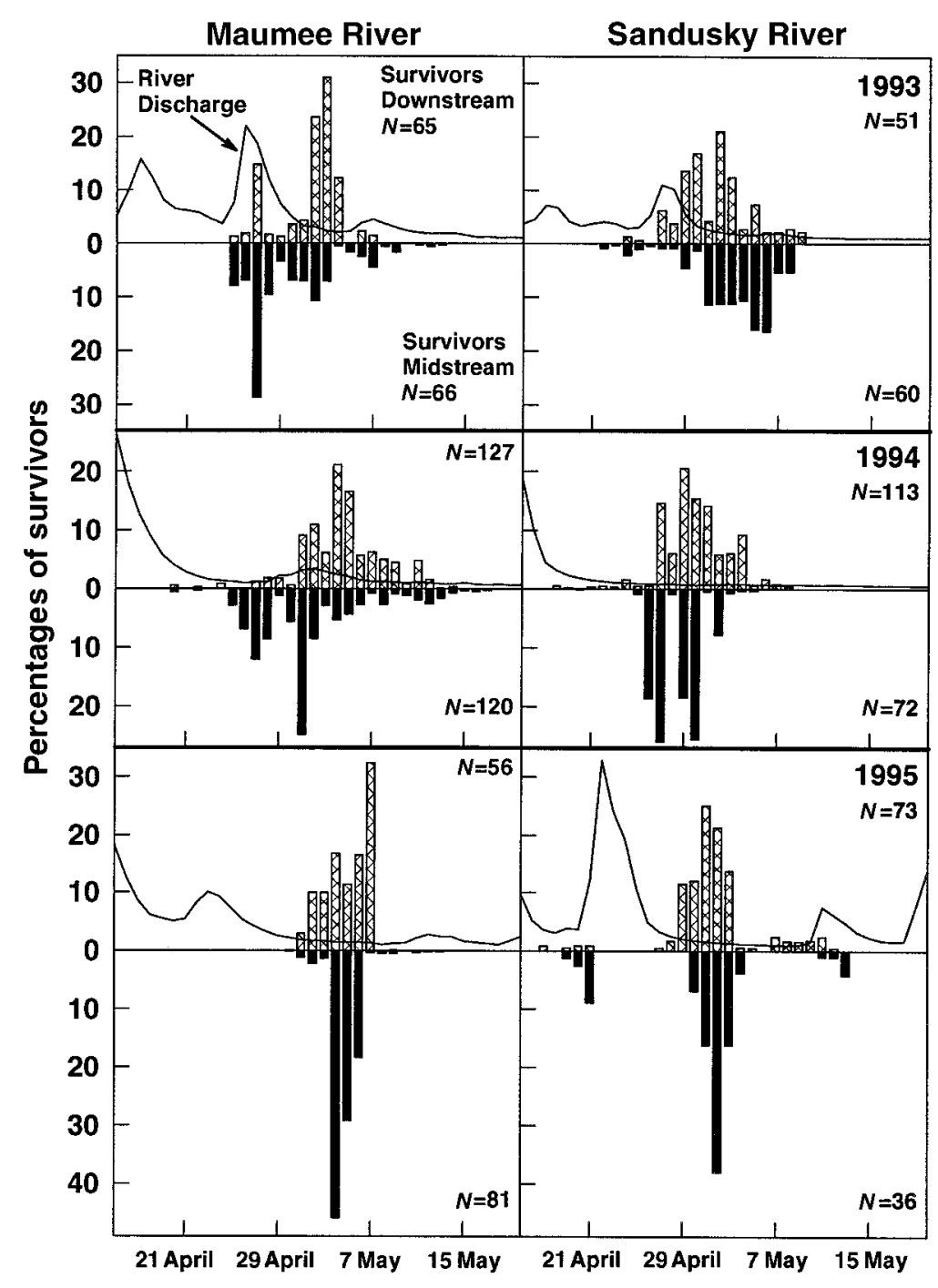

Fig. 4. Comparison between hatch-date distributions of survivors to midstream (filled bars) and downstream (crosshatched bars) sample sites during 1993-1995 in the Maumee and Sandusky rivers, Ohio. Midstream hatch date distributions are duplicated from Fig. 3 to allow direct visual comparison with downstream hatch date distributions. Filled bars represent daily percentages of total survivors to midstream sites attributable to individual hatch dates, and crosshatched bars represent daily percentages of total survivors to downstream sites attributable to individual hatch dates. To increase figure clarity, $y$-axes $\left(\mathrm{m}^{3} / \mathrm{s}\right)$ are not shown for discharge curves.

Juvenile walleye CPUE was correlated negatively with river discharge during May (Fig. 7). These relationships reflect patterns similar to those for IS and discharge in that high juvenile abundance occurred only during low river discharge years, whereas high river discharge resulted in much lower juvenile abundance. 
Table 2. Comparison of percentage of larval production and survival occurring during discrete annual periods of high larval survival to downstream sample sites in the Maumee and Sandusky rivers, Ohio, 1993-1995. Periods of high survival were calculated as the minimum number of days needed to account for at least $75 \%$ of total survivors. Actual percentages of survivors from this subset of days are given in the last column. Production is presented as the percentage of annual production occurring during each period. Durations of total production periods are given in Table 1.

\begin{tabular}{cllcc}
\hline \hline \multirow{2}{*}{ System } & Year & High survival hatch dates & $\begin{array}{c}\text { Production } \\
(\boldsymbol{\%})\end{array}$ & $\begin{array}{c}\text { Survivors } \\
(\%)\end{array}$ \\
\hline Maumee River & 1993 & 27 April, 2-4 May & 25.5 & 81.8 \\
& 1994 & 1-7 May & 41.3 & 75.6 \\
Sandusky River & 1995 & 4-7 May & 5.1 & 76.9 \\
& 1993 & 23, 25, 26, 28, 29 April & 52.1 & 77.7 \\
& 1994 & 1 May & 22.1 & 80.0 \\
& 1995 & 29 April-1, 4 May & 17.3 & 83.6 \\
\hline
\end{tabular}

\section{Discussion}

\section{Walleye recruitment success}

Typically, variability in year class strength of fishes derives from high and variable mortality during early life history stages. Some disagreement exists, however, concerning whether processes regulating year class strength primarily operate during larval (Crecco and Savoy 1985, Myers and Cadigan 1993) or post-larval (Forney 1976, Sissenwine 1984, Peterman et al. 1988) stages. Year class strength for freshwater fishes with large larvae (like walleye) may occur through density-dependent mechanisms operating during the juvenile stage (Houde 1994). In contrast, we believe that year class strength of river-spawned walleye is determined by density-independent factors exerting their influence early in the larval stage, per earlier studies of both river-spawning walleye (Priegel 1970, Johnston et al. 1995) and reef-spawning walleye in Lake Erie (Busch et al. 1975, Roseman et al. 1996). Episodic storms appear to drive survival of larvae, in turn determining walleye year class strength.

River discharge strongly regulated larval walleye survival in the Maumee and Sandusky rivers across three years. Early- and late-hatching larvae survived poorly, whereas larvae hatching during mid-period $\sim 1$ May survived well (as no storms occurred $\sim 1$ May during our 3 yr of sampling), greatly contributing to walleye year class strength. During periods when larvae are most susceptible to intense mortality, subsets of larvae survived well, owing to sometimes brief, yet dramatic, combinations of abiotic and biotic conditions conducive to increased survival. Our findings are consistent with other otolith-based, hatch-date analyses (Methot 1983, Crecco and Savoy 1985, 1987, Rice et al. 1987), in spite of the range of species (four represented), hatch sizes (2.9-9.5 mm), and systems (rivers: Crecco and Savoy 1985, 1987; freshwater lakes: Rice et al. 1987; oceans: Methot 1983). Mechanisms driving these patterns may differ, but the patterns themselves generalize across systems and species.

Production and survival interact to determine recruitment success. Although larval walleye densities in the bays were unrelated to annual production of larvae in the rivers, larval production during high survival periods can influence walleye year class strength substantially. For example, total larval production in the Maumee River during 1995 (our weakest year class) was about twice that in 1994 (our strongest year class). However, production during high 
survival was almost 4.5 times greater in 1994 than in 1995, suggesting that a fine-scale match/mismatch (sensu Cushing 1975) between larval production and environmental conditions drives walleye year class strength. Our assessments of high survival periods were based on relative daily percentages of larvae surviving river out-migration, rather than on absolute numbers surviving. By identifying hatch dates with "high survival'" probabilities, we are only generating predictions relative to other hatch dates within a year. Larval production during high survival periods was similar in 1993 and 1994; yet, overall survival was greater in 1994. Apparently, conditions, even during high survival, were more conducive to strong larval survival in 1994 than 1993.

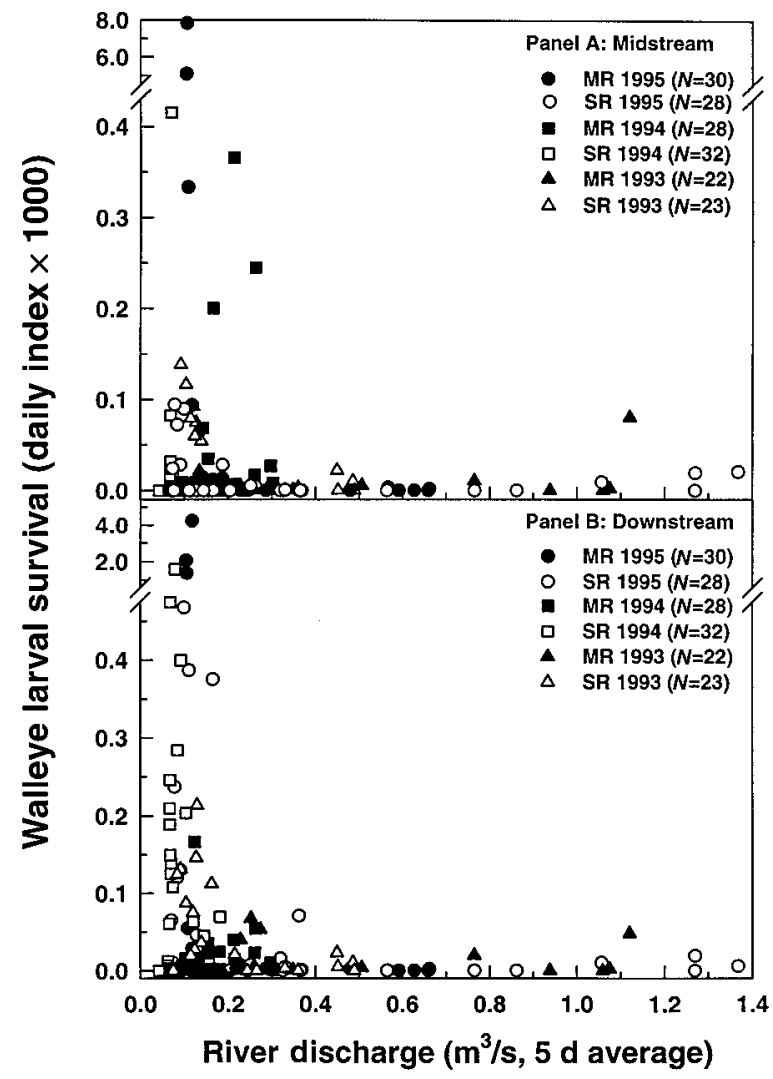

Fig. 5. Relationship between daily index of survival (IS) of walleye larvae at midstream (upper panel) and downstream (lower panel) sites and river discharge for the Maumee (MR) and Sandusky (SR) rivers, Ohio, during 1993-1995. River discharge was the mean daily discharge for the $5 \mathrm{~d}$ following each hatching date for which we calculated survival, which integrated discharge conditions over out-migration. Discharge also was normalized to allow direct comparisons between rivers by dividing discharge by the cross-sectional area of each river channel (Maumee River, $450.0 \mathrm{~m}^{2}$; Sandusky River, $145.1 \mathrm{~m}^{2}$ ). Sample sizes represent the total number of hatch dates for each year in each river (see Table 1).

\section{Mechanisms underlying larval walleye survival}

River discharge and suspended sediments.-We originally hypothesized that survival of larval walleye would increase with river discharge, moving larvae more quickly to productive bays. However, survival of larval walleye was strongly and negatively related to discharge. In 
other river-spawned larval fishes, both direct (Harvey 1987) and indirect (Crecco and Savoy 1985) negative effects of discharge have been documented. In our view, direct discharge-related mortality, occurring early in out-migration, derived from increased suspended sediment which typically coincided with high, turbulent discharge. Suspended sediments can cause gill damage and suffocation in larval fishes (Cordone and Kelley 1961), and create strong scouring action that can damage fragile, newly hatched larval fishes (Lloyd 1987). As egg incubation areas for walleye in the Maumee and Sandusky rivers are shallow gravel-cobble riffles, turbulent flow could kill emerging walleye larvae by driving them against the substratum. Damaged (torn and abraded) larvae were common in our upstream samples, especially during the early portion of the hatch. Thus, discharge and suspended sediments probably interact to create a substantial bottleneck to walleye recruitment immediately post-hatch.

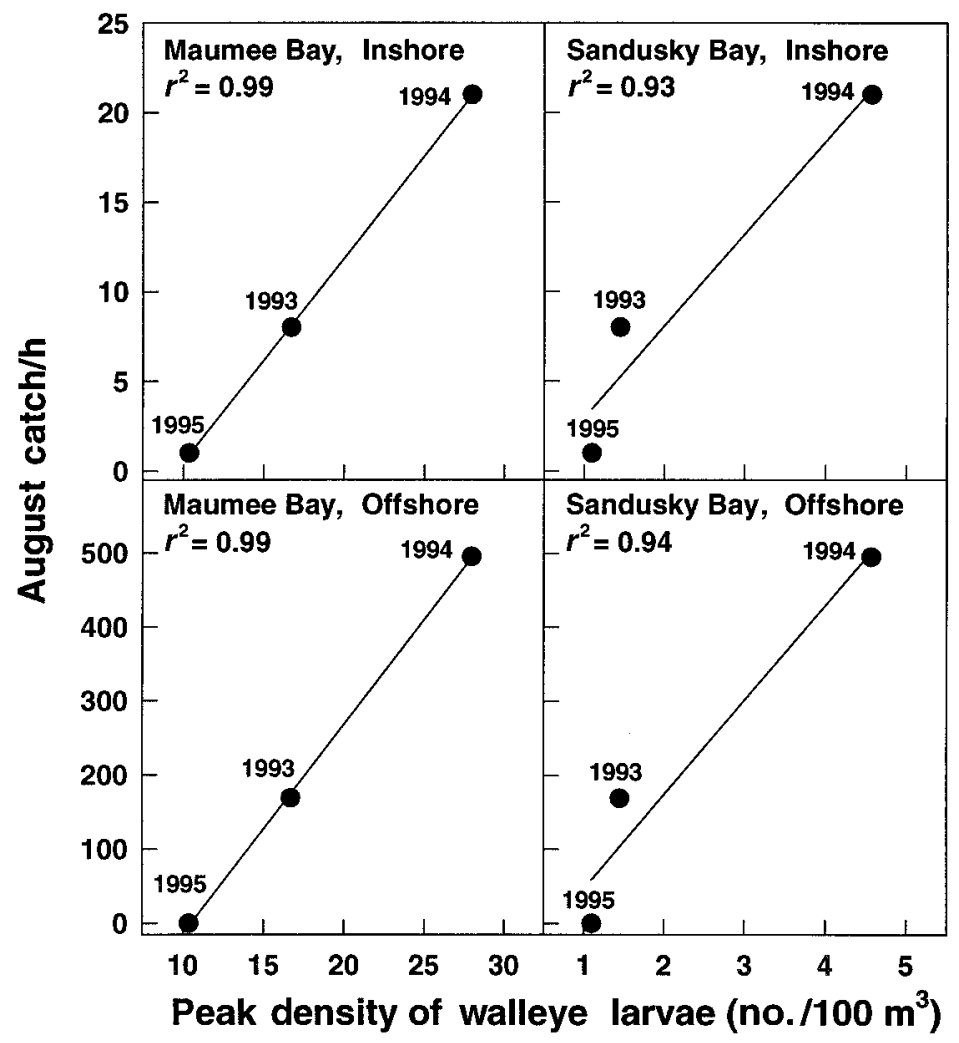

Fig. 6. Relationship between juvenile walleye catch per unit effort (CPUE; Ohio Division of Wildlife 1996) bottom trawling from Lake Erie in August and peak density of larval walleye in Maumee and Sandusky bays, Ohio, 19931995. Inshore estimates reflect CPUE at trawling stations of 3-m depth, whereas offshore estimates reflect CPUE at stations of 9-m depth.

River discharge also may affect survival of larval walleye indirectly by mediating larval river residence time. Low gradients, coupled with lake influxes, make still water and flow reversals common in the lower reaches of the Maumee and Sandusky rivers (Bedford 1992). Prolonged larval river residence under these conditions may compromise survival. Thus, downstream passage through hydrographically variable areas may be critical to larval walleye 
success.

Water temperature and zooplankton density.-Survival of larval walleye in rivers may derive from a complex set of interactions among discharge, water temperature, and zooplankton density. At high discharge, survival was low, irrespective of temperature or food. In turn, those few larvae that survive hatching at high discharge experience short river residence, thus bypassing temperature-zooplankton effects expected with extended river residence. At low discharge, rapid warming (and thus rapid yolk metabolism) and low zooplankton density may reduce larval condition and survival. As larval walleye typically occur in these rivers during periods of rapid warming, zooplankton density would be critical to their success during low discharge years (sensu Crecco and Savoy 1985, 1987). Indeed, atypically high zooplankton density at the downstream site in the Sandusky River during 1994 was associated with successful feeding and high survival of larval walleye.

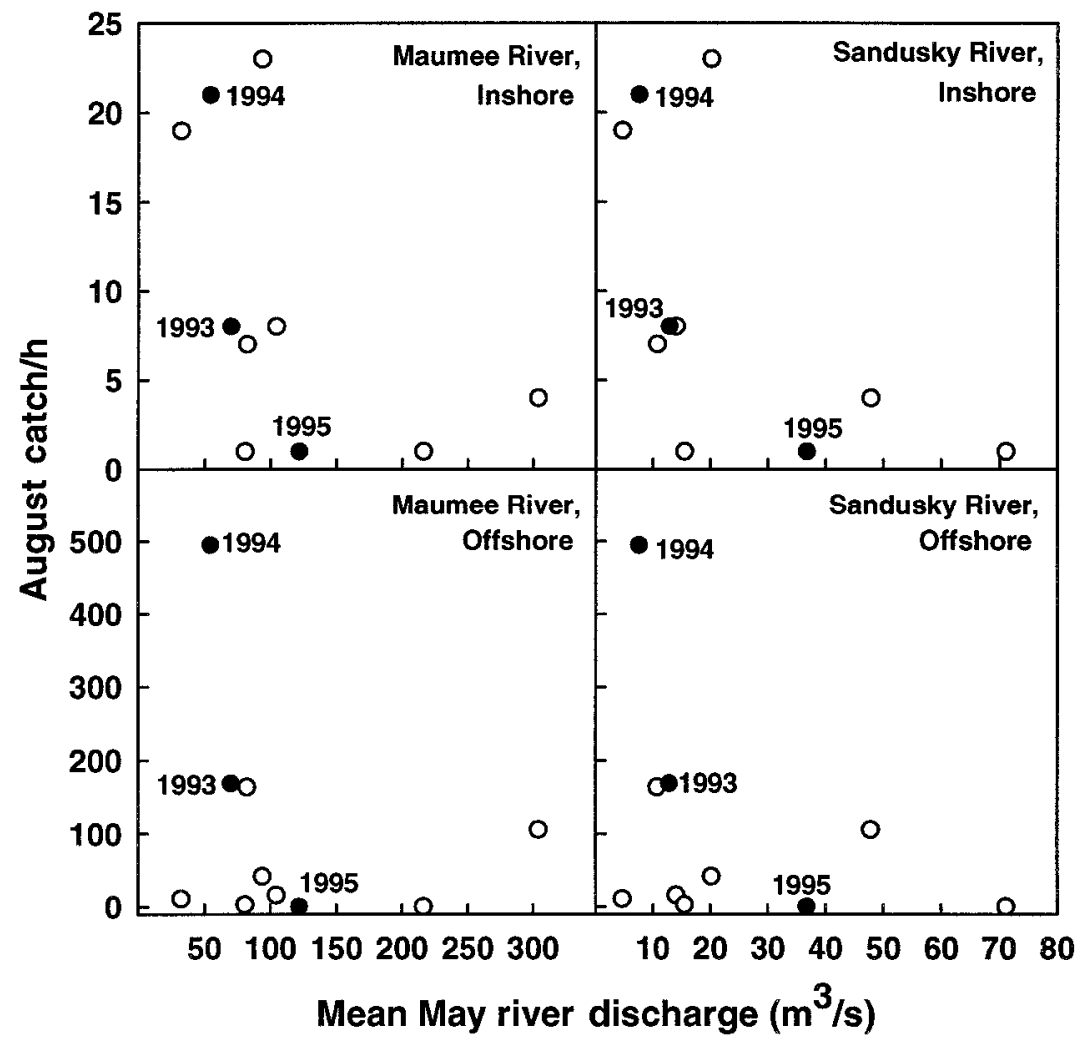

Fig. 7. Relationship between juvenile walleye CPUE (Ohio Division of Wildlife 1996) from Lake Erie in August and mean daily discharge from the Maumee and Sandusky rivers, Ohio, during May 1986-1995. The years of the present study are noted as filled circles. Inshore estimates reflect CPUE at trawling stations of 3-m depth, whereas offshore estimates reflect CPUE at stations of 9-m depth.

Predation.-Predation can influence recruitment success of larval fishes (Hunter 1981). Newly hatched walleye larvae, emerging in large numbers, may be especially attractive to predators. In tributaries to Oneida Lake, New York, predators congregate and feed on larval walleye as they emerge from the substratum (Regier et al. 1969). Many walleye predators, 
including white perch (Morone americana), white bass (Morone chrysops), and yellow perch (Perca flavescens) (Colby et al. 1979), migrate up the Maumee and Sandusky rivers during early to mid-May to spawn in the same habitats used by walleye (Schaeffer and Margraf 1987). Thus, late-hatching larval walleye may face a substantial predatory gauntlet immediately upon hatching. In our work, low survival of late-hatching walleye occurred despite typically low discharge, a pattern consistent with predation as an explanation.

Synthesis of mechanisms.-Regular patterns of larval walleye survival in our rivers may derive from a spatiotemporal progression of abiotic and biotic factors driving larval survival (Fig. 8). Upon hatching, discharge primarily determined larval survival. Because discharge was typically highest during mid- to late-April (after which it declined greatly, except during 1995), early-hatched larvae experienced high discharge-related mortality. Although mid- and latehatched larvae were less likely to experience high discharges, stochastic storm-related high discharges also could occur during these periods. Predation effects most likely concentrate on late-hatching larvae. Thus, mid-hatching larvae typically experience low discharges and little predation, resulting in consistently high survival to the midstream site relative to earlier and later periods of the hatch (Fig. 8).

Though most larval mortality likely occurs between up- and midstream sites, mechanisms operating between mid- and downstream sites may further refine temporal distributions of downstream survivors. The few early-hatching larvae surviving initial high discharges may survive well through the river as low temperatures slow yolk metabolism, ensuring energetic reserves in the face of low food availability (Fig. 8). Similarly, mid-hatching larvae, experiencing moderate temperatures and variable food availability (e.g., zooplankton can occur in relatively high densities, as in the Sandusky River during 1994), should survive well through the lower river. Late-hatching larvae, however, require high zooplankton abundance as they typically face high, energetically demanding temperatures with resulting high mortality. Ultimately, interactions among the timing of storms, predators, high temperatures, and zooplankton availability likely determines the formation and persistence of periods of high survival (Fig. 8).

Though size-dependent mortality explains recruitment variability in some fishes (Miller et al. 1988), these processes may be less important for river-spawned walleye. Direct effects of turbid river discharge upon larval walleye are probably not size selective across the size range of newly hatched larvae. In turn, predation likely would not be size dependent. Weak swimming ability of larval walleye (Houde 1969), coupled with large predators (mature white perch, white bass, and yellow perch), ensures a high capture probability for predators (Miller et al. 1988). In our view, variability in size among individual walleye larvae is much less important than time of hatching in driving their survival probabilities.

Abiotic factors can have powerful, albeit usually indirect (via biotic interactions such as food production, predation, etc.), effects on population and community dynamics (Dunson and Travis 1991). Large-scale climatic events structure fish recruitment variability, acting to regulate proximate factors (Smith and Eppley 1982, Legendre and Demers 1984). Our results are unique, however, in that the regular (as opposed to intermittent or catastrophic) direct influence of an abiotic factor, river discharge, on larval fish survival occurred during three years. Given the direct link with larval survival, climatic conditions during the hatch may accurately, though qualitatively, predict walleye year class strength.

That both bay densities of larval walleye and mean May river discharge are strongly related to August abundance of juvenile walleye in Lake Erie suggests that either (1) river-spawned 
walleye are the largest contributor to the Lake Erie walleye population, or (2) that mechanisms driving survival of reef-spawned larval walleye are similar to those mechanisms operating on river-spawned larvae. The first possibility is unlikely as most Lake Erie walleye spawn on openlake reefs (R. Knight, Ohio Division of Wildlife, Fisheries Research Unit, Sandusky, Ohio, personal communication). In our view, the second possibility, however, is quite plausible. Survival of eggs and newly hatched larvae on the reefs is negatively related to storms and high wind events, owing to the abrasive action of waves and the washing of eggs from protective reef substrate (Busch et al. 1975, Roseman et al. 1996). Walleye spawn in rivers several weeks before reefs as rivers warm more rapidly in spring than the lake (Parrish et al. 1989). Because of differences in spawning times, walleye life stages most vulnerable to storm effects (yolk-sac larvae in the rivers, eggs on the reefs) overlap in time, storms may ultimately regulate survival in both habitats. Earlier observations of synchrony of fish year class strengths over large geographic areas in freshwater (Koonce et al. 1977) and marine (Koslow 1984) systems as generated by large-scale climatic processes are consistent with this perspective. Linkage between survival from rivers and reefs provides insight into the extreme historical variability in Lake Erie walleye recruitment, variability greater than if survival was determined independently in these two habitats.

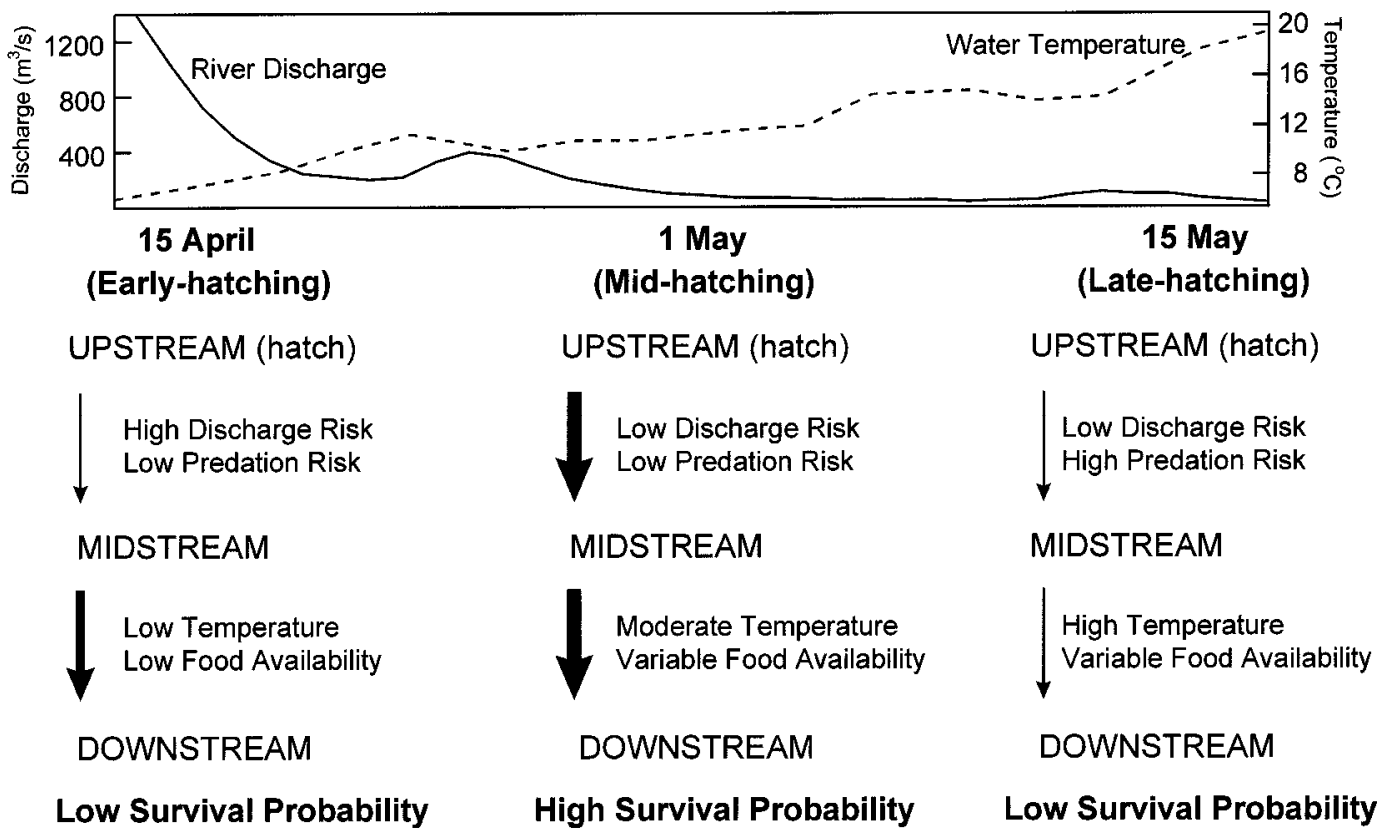

Fig. 8. Conceptual model of generalized trends in river discharge and water temperature (e.g., data from Maumee River, 1995) during the larval walleye hatch coupled with the spatiotemporal influence of river discharge, predation, water temperature, and zooplankton density on survival of larval walleye during river out-migration. Interactions between time of hatching (early-, mid-, and late hatching) and river location (up-, mid-, and downstream) largely determine which mechanisms are most important in determining larval survival. Arrows indicate movement between sites of larvae hatched during different periods (increased arrow thickness indicates increased relative probability of larval survival). Factors influencing larval survival at that location are listed next to each arrow. 


\section{Management implications}

Gaining an appreciation of what factors drive walleye recruitment allows managers to anticipate year class fluctuations. As the terminal predator, large annual variations in walleye year class strength translates to strong community-wide effects, where predation by walleye drives species composition and variation in the Lake Erie fish community (Knight and Vondracek 1993; M. Kershner, Aquatic Ecology Laboratory, The Ohio State University, Columbus, Ohio, personal communication). By regulating prey, walleye effects may then cascade through multiple trophic levels (sensu Carpenter et al. 1985). Thus, understanding mechanisms regulating walleye abundance in Lake Erie is a necessary first step in understanding community structure and function.

Lake Erie continues to be beset by lake-wide perturbations, such as changing nutrient status and invasions of exotic species. Further, even larger scale perturbations, such as global warming, probably will influence formation of walleye year classes by altering patterns of precipitation and streamflow. Storms are predicted to increase in frequency and intensity during late winter and early spring, resulting in greater and more variable streamflows (Nemec and Schaake 1982, Gleick 1987) during the critical larval stage for walleye. Thus, managers should expect a general decline in walleye year class strength and, consequently, population size in response to global warming, with strong year classes becoming increasingly rare. However, improving land use practices to reduce overland flow and sediment input would improve conditions for survival of larval walleye by reducing periods of extremely high discharges and turbidity. Incorporating landscape perspectives into management policies could provide effective, proactive measures for blunting effects of climate change on river-spawned larval fishes.

Maximizing temporal breadth of larval production in rivers also should contribute to stabilizing the variability of walleye year class strength. At present, spawning walleye are subject to intense angling pressure in the Maumee and Sandusky rivers. Because high larval survival can arise even from periods of low production, we feel regulations limiting angling pressure on spawners may increase walleye production. Further, as numbers of spawners are low during the early and late periods of the walleye hatch, these adults should be protected from angling. Although these were typically low survival periods during 1993-1995, the stochastic nature of storms makes it quite likely that discharge patterns during these times could support high survival in future years. Conceivably, these spawners could produce, based on weather conditions, abundant survivors. As such, maximizing larval production over the longest possible interval should increase total numbers of surviving larvae. By limiting angling to 1-2 wk during mid-hatch, at which time spawner densities may be highest, managers could protect early and late larval-production periods to the advantage of walleye. Holistic management policies, coupling watershed management with efforts to maintain the current lengths of larval-production periods, should reduce variability in walleye year class strength in the face of increasing climatic and ecosystem variability.

\section{Acknowledgments}

We are deeply indebted to Mr. and Mrs. D. Millinger, D. Stevens of The Tackle Box, and R. Zoller of Riverfront Marina for generously providing unlimited access to their boat ramps and facilities. We thank E. Bihn, E. Briesemeister, B. Burke, D. Cray, C. Curtis, T. Hess, R. Holmes, S. Odee, D. Ondrey, C. Porter, and A. Rigsby for their help in the field and laboratory. Advice on technical and theoretical issues was provided by M. Bremigan, M. Kershner, S. Ludsin, C. 
Madenjian, E. Roseman, and R. Wright. Insight into otolith aging was generously provided by Gary Fitzhugh, NMFS Southeast Fisheries Science Center. The cooperation and assistance of Ohio Division of Wildlife personnel, most notably, Ken Paxton, Roger Knight, and the staffs of the Sandusky and Fairport Harbor Fisheries Research Units, contributed greatly to the development and execution of this project. This manuscript was substantially improved by reviews from $\mathrm{M}$. Bremigan, $\mathrm{H}$. Regier, and an anonymous reviewer. This work was funded by Federal Aid in Sport Fish Restoration Program project F-69-P, administered jointly by the U.S. Fish and Wildlife Service and the Ohio Division of Wildlife.

\section{Literature Cited}

Auer, N. A., editor. 1982. Identification of larval fishes of the Great Lakes basin with emphasis on the Lake Michigan drainage. Great Lakes Fishery Commission Special Publication 82-3.

Bailey, K. M. 1981. Larval transport and recruitment of Pacific hake (Merluccius productus). Marine Ecology Progress Series 6:1-9.

Bedford, K. W. 1992. The physical effects of the Great Lakes on tributaries and wetlands. A summary. Journal of Great Lakes Research 18:571-589.

Bulkowski, L., and J. W. Meade. 1983. Changes in phototaxis during early development of walleye. Transactions of the American Fisheries Society 112:445-447.

Busch, W. D. N., R. L. Scholl, and W. L. Hartman. 1975. Environmental factors affecting the strength of walleye (Stizostedion vitreum vitreum) year-classes in western Lake Erie. Journal of the Fisheries Research Board of Canada 32:1733-1743.

Carpenter, S. R., J. F. Kitchell, and J. R. Hodgson. 1985. Cascading trophic interactions and lake productivity. BioScience 35:634-639.

Colby, P. J., R. E. McNicol, and R. A. Ryder. 1979. Synopsis of biological data on the walleye (Stizostedion vitreum vitreum Mitchill 1818). Food and Agricultural Organization of the United Nations Fisheries Synopsis 119.

Corbett, B. W., and P. M. Powles. 1986. Spawning and larval drift of sympatric walleye and white suckers in an Ontario stream. Transactions of the American Fisheries Society 115:41-46.

Cordone, A. J., and D. W. Kelley. 1961. The influences of inorganic sediment on the aquatic life of streams. California Fish and Game 47:189-228.

Crecco, V. A., and T. F. Savoy. 1985. Effects of biotic and abiotic factors on growth and relative survival of young American shad (Alosa sapidissima) in the Connecticut River. Canadian Journal of Fisheries and Aquatic Sciences 42:1640-1648.

Crecco, V. A., and T. F. Savoy. 1987. Effects of climate and density-dependent factors on intra-annual mortality of larval american shad. American Fisheries Society Symposium 2:69-81.

Crowder, L. B., J. A. Rice, T. J. Miller, and E. A. Marschall. 1992. Empirical and theoretical approaches to sizebased interactions and recruitment variability in fishes. Pages 237-255 in D. DeAngelis and L. Gross, editors. Individual-based approaches in ecology: concepts and individual models. Chapman and Hall, New York, New York, USA.

Cushing, D. H. 1975. Marine ecology and fisheries. Cambridge University Press, Cambridge, England.

De Sante, D. F. 1990. The role of recruitment in the dynamics of a Sierran subalpine bird community. American Naturalist 136:429-445.

Dunson, W. A., and J. Travis. 1991. The role of abiotic factors in community organization. American Naturalist 138:1067-1091.

Fischer, J. M., and M. V. Moore. 1993. Juvenile survival of a planktonic insect: effects of food limitation and predation. Freshwater Biology 30:35-45.

Forney, J. L. 1976. Year-class formation in the walleye (Stizostedion vitreum vitreum) population of Oneida Lake, New York, 1966-73. Journal of the Fisheries Research Board of Canada 33:783-792.

Franzin, W. G., and S. M. Harbicht. 1992. Tests of drift samplers for estimating abundance of recently hatched walleye larvae in small rivers. North American Journal of Fisheries Management 12:396-405.

Garvey, J. E., E. A. Marschall, and R. A. Wright. 1998. From star charts to stoneflies: detecting relationships in continuous bivariate data. Ecology 79, in press.

Gleick, P. H. 1987. Regional hydrologic consequences of increases in atmospheric $\mathrm{CO}_{2}$ and other trace gases. Climate Change 10:137-161.

Gulland, J. A. 1982. Why do fish numbers vary? Journal of Theoretical Biology 97:69-75. 
Hartman, W. L. 1972. Lake Erie: effects of exploitation, environmental changes, and new species on the fishery resources. Journal of the Fisheries Research Board of Canada 29:899-912.

Harvey, B. C. 1987. Susceptibility of young-of-the-year fishes to downstream displacement by flooding. Transactions of the American Fisheries Society 116:851-855.

-------. 1991. Interaction of abiotic and biotic factors influences larval fish survival in an Oklahoma stream. Canadian Journal of Fisheries and Aquatic Sciences 48:476-1480.

Hatch, R. W., S. J. Nepsy, K. M. Muth, and C. T. Baker. 1987. Dynamics of the recovery of the western Lake Erie walleye (Stizostedion vitreum vitreum) stock. Canadian Journal of Fisheries and Aquatic Sciences 44:1522.

Houde, E. D. 1969. Sustained swimming ability of larvae of walleye and yellow perch. Journal of the Fisheries Research Board of Canada 26:1647-1659.

--------. 1987. Fish early life dynamics and recruitment variability. American Fisheries Society Symposium 2:1729.

1989. Comparative growth, mortality, and energetics of marine fish larvae. Fishery Bulletin 87:471-495.

1994. Differences between marine and freshwater fish larvae: implications for recruitment. ICES (International Council for the Exploration of the Sea) Journal of Marine Science 51:91-97.

Hunter, J. R. 1981. Feeding ecology and predation of marine fish larvae. Pages 33-79 in R. Lasker, editor. Marine fish larvae. Washington Sea Grant, University of Washington Press, Seattle, Washington, USA.

Johnston, T. A., M. N. Gaboury, R. A. Janusz, and L. R. Janusz. 1995. Larval fish drift in the Valley River, Manitoba: influence of abiotic and biotic factors, and relationships with future year-class strengths. Canadian Journal of Fisheries and Aquatic Sciences 52:2423-2431.

Jones, C. 1986. Determining age of larval fish with the otolith increment technique. Fishery Bulletin 84:91-104.

Knight, R. L., and B. Vondracek. 1993. Changes in prey fish populations in western Lake Erie, 1969-88, as related to walleye (Stizostedion vitreum) predation. Canadian Journal of Fisheries and Aquatic Sciences 50:12891298.

Koonce, J. F., T. B. Bagenal, R. F. Carline, K. E. F. Hokanson, and M. Nagiec. 1977. Factors influencing year-class strength of percids: a summary and a model of temperature effects. Journal of the Fisheries Research Board of Canada 34:1900-1909.

Koslow, J. A. 1984. Recruitment patterns in Northwest Atlantic fish stocks. Canadian Journal of Fisheries and Aquatic Sciences 41:1722-1729.

Kruule, H., J. W. H. Conroy, and A. Moorhouse. 1991. Recruitment to a population of otters (Lutra lutra) in Shetland, in relation to fish abundance. Journal of Applied Ecology 28:95-101.

Leach, J. H., and S. J. Nepsy. 1976. The fish community in Lake Erie. Journal of the Fisheries Research Board of Canada 33:622-638.

Legendre, L., and S. Demers. 1984. Towards a dynamic biological oceanography and limnology. Canadian Journal of Fisheries and Aquatic Sciences 41:2-19.

Leggett, W. C., and E. DeBlois. 1994. Recruitment in marine fishes: is it regulated by starvation and predation in the egg and larval stages? Netherlands Journal of Sea Research 32:119-134.

Lloyd, D. S. 1987. Turbidity as a water quality standard for salmonid habitats in Alaska. North American Journal of Fisheries Management 7:34-45.

May, R. C. 1974. Larval mortality in marine fishes and the critical period concept. Pages 3-20 in J. H. S. Blaxter, editor. The early life history of fish. Springer-Verlag, Berlin, Germany.

Methot, R. D. 1983. Seasonal variation in survival of larval northern anchovy (Engraulis mordax) estimated from the age distribution of juveniles. Fishery Bulletin 81:741-750.

Michaletz, P. H. 1986. Validating the use of counting growth rings on otoliths to age young walleyes. South Dakota Department of Game, Fish, and Parks, Report 86-1, Pierre, South Dakota, USA.

Miller, T. J., L. B. Crowder, J. A. Rice, and E. A. Marschall. 1988. Larval size and recruitment mechanisms in fishes: toward a conceptual framework. Canadian Journal of Fisheries and Aquatic Sciences 45:1657-1670.

Myers, R. A., and N. G. Cadigan. 1993. Is juvenile natural mortality in marine demersal fish variable? Canadian Journal of Fisheries and Aquatic Sciences 50:1591-1598.

Nelson, W. R., M. C. Ingham, and W. E. Schaaf. 1977. Larval transport and year-class strength of Atlantic menhaden (Brevoortia tyrannus). Fishery Bulletin 75:23-41.

Nemec, J., and J. Schaake. 1982. Sensitivity of water resource systems to climate variation. Hydrological Science 27:327-343.

Ney, J. J. 1978. A synoptic review of yellow perch and walleye biology. American Fisheries Society Special Publication 11:1-12. 
Norcross, B. L., and R. F. Shaw. 1984. Oceanic and estuarine transport of fish eggs and larvae: a review. Transactions of the American Fisheries Society 113:153-165.

O’Donoghue, M. 1994. Early survival of juvenile snowshoe hares. Ecology 75:1582-1592.

Ohio Division of Wildlife. 1996. Ohio's Lake Erie fisheries, 1995. Ohio Department of Natural Resources, Division of Wildlife, Columbus, Ohio, USA.

Ostfeld, R. S., and C. D. Canham. 1993. Effects of meadow vole population density on tree seedling survival in old fields. Ecology 74:1792-1801.

Parrish, D. L., W. J. Eckmayer, and B. Vondracek. 1989. Age-structured recruitment of young-of-the-year fishes in Lake Erie. Ecology and population dynamics of Lake Erie fishes, Annual Performance Report, Project F61-R-2, Ohio Department of Natural Resources, Division of Wildlife, Columbus, Ohio, USA.

Pepin, P., and T. J. Miller. 1993. Potential use and abuse of general empirical models of early life history processes in fish. Canadian Journal of Fisheries and Aquatic Sciences 50:1343-1345.

Peterman, R. M., M. J. Bradford, N. C. H. Lo, and R. D. Methot. 1988. Contribution of early life stages to interannual variability in recruitment of nothern anchovy (Engraulis mordax). Canadian Journal of Fisheries and Aquatic Sciences 45:8-16.

Priegel, G. R. 1970. Reproduction and early life history of the walleye in the Lake Winnebago region. Wisconsin Department of Natural Resources Technical Report 47.

Regier, H. A., V. C. Applegate, and R. A. Ryder. 1969. The ecology and management of the walleye in western Lake Erie. Great Lakes Fishery Commission Technical Report 15.

Regier, H. A. and W. L. Hartman. 1973. Lake Erie's fish community: 150 years of cultural stresses. Science 180: 1248-1255.

Rice, J. A., L. B. Crowder, and M. E. Holey. 1987. Exploration of mechanisms regulating larval survival in Lake Michigan bloater: a recruitment analysis based on characteristics of individual larvae. Transactions of the American Fisheries Society 116:703-718.

Rice, J. A., T. J. Miller, K. A. Rose, L. B. Crowder, E. A. Marschall, A. S. Trebitz, and D. L. DeAngelis. 1993. Growth rate variation and larval survival: inferences from an individual-based size-dependent predation model. Canadian Journal of Fisheries and Aquatic Sciences 50:133-142.

Roseman, E. F., W. W. Taylor, D. B. Hayes, R. C. Haas, R. L. Knight, and K. O. Paxton. 1996. Walleye egg deposition and survival on reefs in western Lake Erie (USA). Annales Zoologici Fennici 33:341-351.

Roughgarden, J., S. Gaines, and Y. Iwasa. 1984. Dynamics and evolution of marine populations with pelagic larval dispersal. Pages 111-128 In R. M. May, editor. Exploitation of marine communities. Springer-Verlag, Berlin, Germany.

Sacchi, C. F., and P. W. Price. 1992. The relative roles of abiotic and biotic factors in seedling demography of arroyo willow (Salix lasiolepis: Salicaceae). American Journal of Botany 79:395-405.

Sale, P. F. 1990. Recruitment in marine species: is the bandwagon rolling in the right direction? Trends in Ecology and Evolution 5:25-27.

Schaeffer, J. S., and F. J. Margraf. 1987. Predation on fish eggs by white perch (Morone americana) in western Lake Erie. Environmental Biology of Fishes 18:77-80.

Schneider, J. C. and J. H. Leach. 1977. Walleye (Stizostedion vitreum vitreum) fluctuations in the Great Lakes and possible causes, 1800-1975. Journal of the Fisheries Research Board of Canada 34:1878-1889.

Shelton, and P. A., and L. Hutchings. 1982. Transport of anchovy (Engraulis capensis) eggs and early larvae by a frontal jet current. Journal du Conseil Permanent International pour l'Exploration de la Mer 40:185-198.

Sissenwine, M. P. 1984. Why do fish populations vary? Pages 59-94 in R. M. May, editor. Exploitation of marine communities. Springer-Verlag, Berlin, Germany.

Smith, P. E., and R. W. Eppley. 1982. Primary production and the anchovy population in the Southern California Bight: a comparison of time series. Limnology and Oceanography 27:1-17.

Stahl, T. P., and R. A. Stein. 1994. Influence of larval gizzard shad (Dorosoma cepedianum) density on piscivory and growth of young-of-year saugeye (Stizostedion vitreum $\times$ S. canadense). Canadian Journal of Fisheries and Aquatic Sciences 51:1993-2002.

United States Geological Survey. 1992. Water resource data for Ohio. Volume 2. United States Department of Interior, Washington, D.C., USA.

1995. Water resource data for Ohio. Volume 2. United States Department of Interior, Washington, D.C., USA.

Werner, E. E., and J. F. Gilliam. 1984. The ontogenetic niche and species interactions in size structured populations. Annual Review of Ecology and Systematics 15:393-425. 